\title{
Financial eurization in Croatia and its (non)linear pattern behaviour
}

\author{
Mile Bošnjak* \\ University of Zagreb, Faculty of Economics and Business \\ Trg J. F. Kennedyja 6, HR-10000 Zagreb, Croatia \\ E-mail: <mile.bosnjak76@gmail.com>
}

\begin{abstract}
The phenomenon of financial eurization is prominent in the region of south eastern European countries. This paper examines the phenomenon in Croatia focusing on the liability side of the banking system. Using monthly data from January 1997 to November 2015 univariate time series models are estimated and evaluated. Following research results in this paper nonlinear model specifications outperform ARMA $(3,0,0)$ in explaining financial eurization pattern behavior in Croatia. The research results revealed nonlinear and threshold dependent dynamics of eurization dynamics in Croatia. Empirical evidence out of this paper points out on persistent eurization with hysteresis indicating the need to achieve overall macroeconomic stability in order to resolve the existing phenomenon of financial eurization in Croatia.
\end{abstract}

Keywords: financial eurization, time series, nonlinearity, threshold autoregression, Markov switching

Received: November 16, 2016; accepted: March 22, 2018; available online: July 24, 2018

DOI: $10.17535 /$ crorr.2018.0005

\section{Introduction}

The phenomenon known as dollarization is an extremely hot topic in the region of south eastern European countries. Here is used the term "eurization" to denote the notion of dollarization of financial system in countries where the reference currency is Euro. The dollarization or eurization, as here referred the phenomenon, is a domestic currency substitution process and may have variety in its forms. Extensive overview of different currency substitution forms can be found in [6]. The focus of this paper is directed toward financial eurization or more specifically eurization in commercial banks since the financial systems in south eastern European countries is a bank-centric and this eurization form is the most prominent one. The banking regulators often limit the direct exposure to foreign currency risk in financial institutions by requiring them to keep balanced their lending in foreign currency and foreign currency denominated liabilities. So the key problem comes out of liability side of banking system and therefore the focus is directed toward deposits or liability side euritazion in banking system. There are empirical evidence that foreign currency deposits promote financial deepening and financial intermediation in the countries where the confidence

\footnotetext{
${ }^{*}$ Corresponding author. 
in domestic currency is lost due to high inflation and macroeconomic instability [6]. Some research covers many countries and focus only on the causes and consequences of dollarized bank deposits [7]. The other research found the highest deposits eurization in Croatia and Serbia among the south eastern European sample countries, namely Bosnia and Herzegovina, Bulgaria, Romania, Croatia, Macedonia, Albania, Montenegro and Serbia [23]. Montenegro is excluded since deposits eurization in Montenegro is complete. The eurization phenomenon has been the topic of the previous research papers but univariate modeling approach has not been applied yet to the best knowledge of the author. Univariate analysis is much easier to understand and does not rely on the assumptions of any particular economic theory. The main aim of this research is to determine deposits eurization pattern in Croatia using linear and nonlinear approach as the competing specifications.

The rest of the paper is organized as follows: section 2 summarizes stylized facts and provides brief literature overview. Section 3 presents research data methodology, while section 4 empirical results and discussion. The final section provides an overview of the main findings of the research.

\section{Stylized facts and brief literature overview}

The debate on exchange rate adequacy in Croatia stared with Stabilization Program being implemented in the fall of 1993 is still on. Besides the high eurization financial system, Croatian economy is characterized as a highly open and having relatively high level of the external debt as well. Therefore, the problems arising out of financial eurization in Croatia are very prominent.

Empirical analysis of the domestic and external inflation determinants for eight noneurozone new EU member states including Croatia, using a structural vector auto regression model and found that foreign shocks are a major factor in explaining inflation dynamics in the medium run [9]. This might be the case due to relatively high imports in Croatia. However, stable inflation is important for sound macroeconomic and financial conditions as well as for fostering economic development [10]. Since the financial crisis in 2007 through various monetary policy measures central banks balance sheets has expanded significantly, indicating high increase in money supply [11]. Furthermore, economic theory and historical experience suggest that a significant and persistent expansion in the money supply will be associated with a significant increase in the longer-run inflation rate. If later is a true, Croatia might experience inflation rate increase. At the same time Croatian National Bank cope with EUR/HRK exchange rate stability. Croatian foreign exchange interventions manage both day-to-day exchange rate volatilities as well as exchange rate levels [5]. Furthermore the authors concluded that the pattern of foreign exchange intervention for Croatia confirms a fear of depreciation (with respect to balance sheet effects of the banking sector) more than a fear of appreciation (with respect to export competitiveness). The Croatian National Bank in order to meet its primary objective and maintain prices stabile keeps real [19] as well as nominal EUR/HRK exchange rate stability $[1,17]$. Well known fact is that domestic currency depreciation through real exchange rate undervaluation can boost economic growth, thus being a key variable in promoting economic activity, especially in developing countries [21]. Due to high eurization in commercial banks balance sheets Croatian National Bank could not support the Croatian 
economy by expansionary monetary policy. But as a consequence of monetary expansion by European Central Bank, at one point Croatia might experience adverse effects out of imported inflation from European Monetary Union. Therefore, dealing with eurization in credit institutions should be the topic of high priority for Croatian monetary authorities. Advice for highly euroized countries like Croatia would be to increase nominal exchange rate flexibility and act to reduce both deposit and credit euroization levels during good times, in order to make the financial system more resilient in bad times [28]. Research results on a sample lowincome countries point out that the size and variance of inflation and depreciation are important determinants of deposit dollarization [18]. On a data sample of 32 countries from Latin America, Emerging Europe and Africa exchange rate volatility and macroeconomic stabilization are found to be determinants of financial dollarization [15]. It's empirically confirmed that nominal and real exchange rate changes have a strong effect on financial eurization in Croatia in the long run [13].

The literature on dollarization has documented the phenomenon of Hysteresis pointing out on difference in dollarization and de-dollarization process due to depositors get used to holding foreign currency deposits and do not reverse them back to domestic currency due to some behavioral inertia or habit $[3,22,26,27]$. Taking into account potential hysteresis, nonlinear model might be more appropriate in explaining eurization pattern in Croatia.

\section{Research data and methodology}

Deposits eurization represents foreign exchange deposits to total deposits. The data sample consists of monthly data from January 1997 to November 2015 obtained from Croatian National Bank (CNB). In order to research eurization growth equation (1) is being used:

$$
\mathrm{LNFCD}_{\mathrm{t}}=\log \left(\frac{\mathrm{FCD}_{\mathrm{t}}}{\mathrm{FCD}_{\mathrm{t}-1}}\right)
$$

where $\mathrm{FCD}_{\mathrm{t}}$ denotes eurization level in month $\mathrm{t}, \mathrm{FCD}_{\mathrm{t}-1}$ eurization level in month $\mathrm{t}-1$ and $\mathrm{LNFCD}_{\mathrm{t}}$ is the eurization growth in month t. Negative eurization growth is referred here as deeurization. Table 1 provides descriptive statistics for eurization and eurization growth as well.

\begin{tabular}{|l|c|c|}
\hline & LNFCD & FCD \\
\hline Mean & -0.000404 & 77.88393 \\
\hline Median & -0.000726 & 78.54046 \\
\hline Maximum & 0.022986 & 88.08720 \\
\hline Minimum & -0.028860 & 62.44784 \\
\hline Std. Dev. & 0.007330 & 7.277306 \\
\hline
\end{tabular}

Table 1: Descriptive statistics [Author].

First question in any time series analysis is whether the time series is stationary or not. So the research starts with unit root tests. The unit root tests being performed are based on the assumption that a time series data $\left\{Y_{t}\right\}$ follows a random walk. 


$$
Y_{t}=\rho Y_{t-1}+\varepsilon_{t}
$$

where $\rho$ is the characteristic root of an AR polynomial and $\varepsilon_{t}$ is purely a random process with mean zero and variance $\sigma^{2}$. ARIMA is a well known forecasting technique that projects the future values of a time series and the future value of a series or forecasts are entirely based on its own behavior in the past. ARIMA models are simple, robust and parsimonious while providing good results at the same time. A time series $Y_{t}$ fits Autoregressive Integrated Moving Average (ARIMA) model if the $d^{t h}$ differences $\left(\nabla^{d} Y_{t}\right)$ follow a stationary ARMA model. ARIMA process is described by tree main components [5]: $\mathrm{p}$ - the order of the autoregressive component; $\mathrm{d}$ - the order of integration or the number of differencing needed to arrive at a stationary $\operatorname{ARMA}(\mathrm{p}, \mathrm{q})$ process; and $\mathrm{q}$ - the order of the moving average component. The general ARIMA (p,d,q) form is represented by the equation (3):

$$
\Phi(B)(1-B)^{d} Y_{t}=\theta(B) \varepsilon_{t}
$$

The corresponding AR and MA characteristic polynomial are:

$$
\begin{aligned}
& \Phi(B)=\left(1-\Phi_{1} B-\Phi_{2} B^{2}-\cdots-\Phi_{p} B^{p}\right) \\
& \theta(B)=\left(1-\theta_{1} B-\theta_{2} B^{2}-\cdots-\theta_{q} B^{q}\right)
\end{aligned}
$$

where $\Phi$ - the parameter estimate of the Autoregressive component; $\theta$ - the parameter estimate of the Moving Average component; $B$ - the backward shift operator; and $\nabla$ - the difference operator that can be expressed by equation (6):

$$
\nabla=(1-B)
$$

$\varepsilon_{t}$ - a random process with mean zero; and $\operatorname{var}\left(\varepsilon_{t}\right)=\sigma_{\varepsilon}^{2}$.

In case where $p=0$, model described by equations (3) to (5) becomes a moving average model of order $q$ or MA $(q)$ and in case of $q=0$ it becomes an autoregressive process of order $p$ or $\operatorname{AR}(p)$. Besides stationarity, the other requirement is invertibility or uniqueness of the covariance structure of the time series [19] allowing meaningful association of current moves with the history of the [2]. The autocorrelation function of an MA $(q)$ process cuts off after lag $q$ while for an $\operatorname{AR}(p)$ process the autocorrelation function is a combination of sinusoidals dying off slowly. In a same way partial autocorrelation function of an MA $(q)$ process dies off slowly while for an AR $(p)$ process cuts off after lag $p$. Stationarity and invertibility conditions for model described by equation (3) require that equations (7) and (8) should have roots outside the unit circle respectively:

$$
\begin{aligned}
& \left(1-\Phi_{1} B-\Phi_{2} B^{2}-\cdots-\Phi_{p} B^{p}\right)=0 \\
& \left(1-\theta_{1} B-\theta_{2} B^{2}-\cdots-\theta_{q} B^{q}\right)=0
\end{aligned}
$$

Extensive details on ARIMA modeling can be found in [2] as well as in [17]. Following described procedure ARIMA model is fitted to foreign currency deposit ratio in Croatia and estimates are obtained. 
Afterwards, additional test for non-linearity are applied. Namely, Keenan test that tests the quadratic nonlinearity hypothesis [14], Tsay nonlinearity test [25] and Tong's likelihood ratio test for threshold nonlinearity [4]).

Modeling nonlinear economic time series using regime switching models has gained the popularity in the past two decades. Sudden shifts or breaks in an economic time series violate the linearity and so make an observed series nonlinear. It's often the case due to arising economic or financial crises within the observed time series. To adequately capture the information on development and evolution of such time series exhibiting different properties in a different time periods [12] proposed Markov switching autoregressive (MS-AR) model. MSAR model is one of the most popular regime switching models that explains development of the observable time series depending on the unobserved regime variable.

The Markov-switching models assume a different regression model for each regime. The essential idea of the model is that the observable time series vectors are depend on the unobserved regime variable. The residuals of the estimated regression models are normally distributed and variance may depend on each specific regime. The first order assumption states that the probability of being in a regime depends on the previous state. So the first order assumption may be expressed by the equation (9):

$$
P\left(s_{t}=k \mid s_{t-1}=i\right)=p_{i, k}
$$

Even though is not required, it's often assumed that transition probabilities are not time dependent, time invariant or constant. In that case, the equation (10) holds:

$$
p_{i, k}(t)=p_{i, k}
$$

In this research two state Markov process is applied an therefore two transition probabilities need to be obtained. But nonetheless, the series might exhibit threshold nonlinearity form. This paper further follows the Self Excited Threshold Autoregressive (SETAR) procedure proposed by Tong [24] to examine nonlinear specification with threshold. For the time series $Y_{t}$ SETAR modelcan be represented by the equation (11):

$$
Y_{t}=\mu_{1} I\left(Y_{t-k}>y\right)+\mu_{2} I\left(Y_{t-k} \leq y\right)+\left[\alpha_{1} I\left(Y_{t-k}>y\right)+\alpha_{2} I\left(Y_{t-k} \leq y\right)\right] Y_{t-k}+u_{t}
$$

where the $k$ and $y$ represents delay and threshold, respectively. The equation (11) provides the specification for the two regime SETAR process.

Diagnostics checking for all of the presented specification are performed using JarqueBera test, ARCH test and Breusch-Godfrey LM test of serial correlation among residuals. Eventually, following information criterion the estimated models are compared.

\section{Research results and discussion}

Unit root test results are summarized in Table 2 . 


\begin{tabular}{|l|r|r|r|r|}
\hline \multirow{2}{*}{ Variable } & \multicolumn{3}{|c|}{ Levels } & \multicolumn{2}{c|}{ First difference } \\
\cline { 2 - 5 } & Constant & Constant and trend & Constant & Constant and trend \\
\hline \multirow{2}{*}{ ADF test } & \multicolumn{4}{|c|}{ t-stat } \\
& \multicolumn{3}{|c|}{ (p-value) } \\
\hline \multirow{2}{*}{ FCD } & -0.581298 & -2.543838 & -6.092619 & -6.071872 \\
& $(0.9788)$ & $(0.3068)$ & $(0.0000)$ & $(0.0000)$ \\
\hline \multirow{2}{*}{ LNFCD } & -9.774898 & -9.898923 & -13.96756 & -13.93596 \\
& $(0.0000)$ & $(0.0000)$ & $(0.0000)$ & $(0.0000)$ \\
\hline
\end{tabular}

Table 2: Unit root test results [Author].

Following unit root test results in Table 2 eurization dynamics is stationary time series while eurization level containes unit root and therefore is not stationary. Out of unit root test results the series under consideration may be regarded as diffence stationary process. Afterwards, well known ARIMA procedure has been applied [2]. So, estimating model using the data at first differences does not remove autocorrelations in residuals of the estimated model so the ACF and PACF are insightful. Based on the ACF and PACF, an appropriate ARIMA model should be fund. Since the eurization growth being modeled and the corresponding time series is stationary the estimated model will be ARMA form model. The PACF displays a sharp cutoff after lag 3 while the ACF decays more slowly and so $\operatorname{ARMA}(3,0,0)$ is going to be fitted. Table 3 summarizes ARMA $(3,0,0)$ model estimates for eurization growth.

\begin{tabular}{|l|r|r|r|}
\hline \multicolumn{1}{|c|}{ Model term } & Coefficient & t - statistic & p-value \\
\hline $\mathrm{C}$ & $\begin{array}{r}-0.000360 \\
(0.000961\end{array}$ & -0.374579 & 0.7083 \\
\hline $\mathrm{AR}(1)$ & $\begin{array}{r}0.356039 \\
(0.062648)\end{array}$ & 5.683160 & 0.0000 \\
\hline AR $(3)$ & $\begin{array}{r}0.181569 \\
(0.062506)\end{array}$ & 2.904815 & 0.0040 \\
\hline Log likelihood $=798.1700$ & R squared $=0.193438$ & AIC $=-7.163694$ & SIC $=-7.117711$ \\
\hline
\end{tabular}

Table 3: ARMA(3,0,0) model summary eurization growth in Croatia [Author].

The estimated model in Table 3 is stable since all roots have modulus less than one and lie inside the unit circle and correlogram indicates no autocorrelation in residuals up to leg thirtysix. ARCH test indicates homoskedastic variance of residuals (p-value amounts 0.2094) and therefore the obtained estimates are efficient. However, as stated in methodology section of the paper the series might exhibit the nonlinear properties. In order to test the property of nonlinearity for the series under consideration several nonlinearity tests are employed and results are provided in Table 4.

The results in Table 4 clearly indicate the nonlinear property of eurization growth. Therefore, linear model might be misspecified. So a few nonlinar model forms are estimated and evaluated. To test whether the observed time series exhibits different properties during the eurization and de-eurization MS-AR model is estimated and results are summarized in Table 5. 


\begin{tabular}{|c|r|c|c|c|c|c|}
\hline \multirow{2}{*}{$\begin{array}{c}\text { Observed } \\
\text { series }\end{array}$} & \multicolumn{2}{|c|}{$\begin{array}{c}\text { Keenan (1985) One- } \\
\text { Degree Test For } \\
\text { Nonlinearity }\end{array}$} & \multicolumn{2}{|c|}{$\begin{array}{c}\text { Tsay (1986) Test For } \\
\text { Nonlinearity }\end{array}$} & $\begin{array}{r}\text { Tong (1986) Likelihood Ratio } \\
\text { Test for Threshold } \\
\text { Nonlinearity }\end{array}$ \\
\cline { 2 - 7 } & Test statistic & p- value & $\begin{array}{c}\text { Test } \\
\text { statistic }\end{array}$ & p- value & Test statistic & p- value \\
\hline LNFCD & 17.572077 & $3.8222 \mathrm{e}-05$ & 3.313 & 0.003717 & 24.095560 & 0.001863 \\
\hline
\end{tabular}

Table 4: Nonlinearity tests results [Author].

\begin{tabular}{|l|l|r|r|r|}
\hline \multicolumn{2}{|c|}{ Model term } & Coefficient & t - statistic & p-value \\
\hline \multirow{2}{*}{$\mathrm{C}$} & Regime 1 & $\begin{array}{r}-0.001154 \\
(0.001266)\end{array}$ & -0.912037 & 0.3617 \\
\cline { 2 - 5 } & Regime 2 & $\begin{array}{r}0.017836 \\
(0.003077)\end{array}$ & 5.797077 & 0.0000 \\
\hline \multirow{2}{*}{$\mathrm{AR}(1)$} & $\begin{array}{r}0.393522 \\
(0.067061)\end{array}$ & 5.868085 & 0.0000 \\
\hline $\mathrm{AR}(3)$ & $\begin{array}{r}0.319970 \\
(0.071154)\end{array}$ & 4.496861 & 0.0000 \\
\hline \multirow{2}{*}{$\mathrm{LOG}($ SIGMA) } & $\begin{array}{r}-5.237738 \\
(0.058776)\end{array}$ & -89.11363 & 0.0000 \\
\hline Log likelihood $=821.0374$ & $\mathrm{AIC}=-7.300784$ & H.-Q. $=-7.257608$ & $\mathrm{SIC}=-7.193832$ \\
\hline
\end{tabular}

Table 5: Markov switching model of eurization growth in Croatia with regime specific constant [Author].

Out of Table 5, the one can see the regime specific mean estimates. Estimated mean for regime one is negative and amounts -0.001154 while the estimated mean for regime two amounts 0.017836. Furthermore, regime two is significant at $1 \%$ while regime no is not and therefore the dynamics in regime one is not substantial. Furthermore, [15] shows that if the roots lie inside the unit circle, the estimated AR process is stable. Since in the presented model no root lies outside the unit circle and the modulus is less than one, AR meets the stability requirement. Table 6 shows the matrix containing the probabilities of transition between the states.

\begin{tabular}{|c|c|c|}
\hline Regime & 1 & 2 \\
\hline 1 & 0.798493 & 0.201507 \\
\hline 2 & 0.007251 & 0.992749 \\
\hline
\end{tabular}

Table 6: Constant transition probabilities for the $M S$ - $A R$ model with regime dependent mean [Author].

The time-varying probabilities in Table 6 show considerable state dependence in the transition probabilities with a relatively higher probability of remaining in the regime two. Probability of staying in regime one $\left(P\left(s_{t}=1 \mid s_{t-1}=1\right)\right)$ amounts 0.798493 , while the probability of staying in regime two $\left(P\left(s_{t}=2 \mid s_{t-1}=2\right)\right)$ amounts 0.992749 . Here presented research results indicate 
persistent euroization growth. Dollarization is particularly persistent in countries with poor macroeconomic management and unstable economic conditions [7]. Expected duration for each state is presented in Table 7.

\begin{tabular}{|c|c|c|}
\hline Regime & 1 & 2 \\
\hline Expected duration & 4.962615 & 137.9036 \\
\hline
\end{tabular}

Table 7: Constant expected durations [Author].

Following the results in Table 7, the expected duration of regime one is approximately 5 while the corresponding duration of regime two amounts 138 months indicating that de-eurization growth will not remain in the origin state for a long time before moving to the eurization growth state. Out of comparison of the criterions in Table 3 and Table 5, Log-likelihood value is higher and all of the information criterions are lower for MS-AR model and therefore MS-AR model outperforms $\operatorname{ARMA}(3,0,0)$ in explaining financial eurization pattern behavior in Croatia. Following the same procedure, Table 8 provides estimates for MS-AR model with regime dependent mean and autoregression coefficient.

\begin{tabular}{|c|c|c|c|}
\hline Model term & Coefficient & $\mathrm{t}$ - statistic & p-value \\
\hline \multicolumn{4}{|c|}{ Regime 1} \\
\hline $\mathrm{C}$ & $\begin{array}{r}0.0047 \\
(0.0042)\end{array}$ & 1.1190 & 0.2631 \\
\hline $\mathrm{LNFCD}_{\mathrm{t}-1}$ & $\begin{array}{r}-0.0544 \\
(0.2128) \\
\end{array}$ & -0.2556 & 0.7983 \\
\hline $\mathrm{LNFCD}_{\mathrm{t}-2}$ & $\begin{array}{r}0.0481 \\
(0.5587)\end{array}$ & 0.0861 & 0.9314 \\
\hline $\mathrm{LNFCD}_{\mathrm{t}-3}$ & $\begin{array}{r}0.7562 \\
(0.5407) \\
\end{array}$ & 1.3986 & 0.1619 \\
\hline \multicolumn{4}{|c|}{ Regime 2} \\
\hline $\mathrm{C}$ & $\begin{array}{r}-0.0002 \\
(0.0003) \\
\end{array}$ & -0.6667 & 0.50496 \\
\hline $\mathrm{LNFCD}_{\mathrm{t}-1}$ & $\begin{array}{r}0.4132 \\
(0.0685)\end{array}$ & 6.0321 & $1.618 \mathrm{e}-09$ \\
\hline $\mathrm{LNFCD}_{\mathrm{t}-2}$ & $\begin{array}{r}-0.0132 \\
(0.0445)\end{array}$ & -0.2966 & 0.76677 \\
\hline $\mathrm{LNFCD}_{\mathrm{t}-3}$ & $\begin{array}{r}0.0820 \\
(0.0376)\end{array}$ & 2.1809 & 0.02919 \\
\hline Log likelihood $=946.7444$ & $\mathrm{AIC}=-1877.489$ & $\mathrm{SIC}=-1804$ & .58 \\
\hline
\end{tabular}

Table 8: Markov switching model of eurization growth in Croatia wih regime specific constant and autoregression coefficients [Author]. 
The results in Table 8 consistently with results in Table 5 show no significant estimates for the period of de-eurization. Constant transition probabilites for the model estimated in Table 8 are reported in Table 9.

The results in Table 9 show slightly different constant transition probabilities but the conclusion still remains. Tong (1986) Likelihood ratio test for threshold Nonlinearity indicated threshold nonlinearity and following Pooled AIC criterion the SETAR hyper parameters are estimated and summarized in Table 10.

SETAR hyper parametres in Table 10 illustrates lag one in low and high regime with no delay and following the estimates the SETAR specification of eurization growth in Croatia is estimated and presented in Table 11.

\begin{tabular}{|c|c|c|}
\hline Regime & 1 & 2 \\
\hline 1 & 0.4405636 & 0.08495009 \\
\hline 2 & 0.5594364 & 0.91504991 \\
\hline
\end{tabular}

Table 9: Constant transition probabilities for the $M S$ - $A R$ model with regime dependent mean and autoregression coefficients [Author].

\begin{tabular}{|c|c|c|c|c|c|c|c|c|}
\hline \multirow[t]{2}{*}{ Variable } & \multicolumn{6}{|c|}{ SETAR Hyper parameters } & \multirow{2}{*}{$\begin{array}{l}\text { Number of } \\
\text { Possible } \\
\text { Threshold } \\
\text { Value }\end{array}$} & \multirow{2}{*}{$\begin{array}{c}\text { Number of } \\
\text { Threshold Values } \\
\text { tested with Hyper } \\
\text { Parameters }\end{array}$} \\
\hline & $\mathrm{m}$ & $\begin{array}{c}\text { Threshold } \\
\text { Delay }\end{array}$ & $\mathrm{mL}$ & $\mathrm{mH}$ & $\begin{array}{c}\text { Threshold } \\
\text { Value }\end{array}$ & $\begin{array}{c}\text { Pooled } \\
\text { AIC }\end{array}$ & & \\
\hline LNFCD & 3 & 0 & 1 & 1 & -0.1402260 & -271.55 & 184 & 46 \\
\hline
\end{tabular}

Note: $\mathrm{m}$ denotes The autoregressive level of the whole model; Threshold Delay denotes the delay level of the Self-excited model and $\mathrm{mL}$ denotes low regime level, $\mathrm{mH}$ : High regime level.

Table 10: SETAR Hyper parameters [Author].

\begin{tabular}{|c|c|c|c|c|}
\hline Regime & Model term & Coefficient & t- Statistic & p-value \\
\hline \multirow{2}{*}{ Low } & $\mu_{1}$ & $\begin{array}{r}-4.23577971 \mathrm{e}-05 \\
(8.3704726 \mathrm{e}-04) \\
\end{array}$ & -0.05060 & 0.95968037 \\
\hline & $\alpha_{1}$ & $\begin{array}{r}4.78043188 \mathrm{e}-01 \\
(1.2909247 \mathrm{e}-01)\end{array}$ & 3.70311 & 0.00026047 \\
\hline \multirow{2}{*}{ High } & $\mu_{2}$ & $\begin{array}{r}4.16605452 \mathrm{e}-03 \\
(1.0605408 \mathrm{e}-03)\end{array}$ & 3.92824 & 0.00010991 \\
\hline & $\alpha_{2}$ & $\begin{array}{r}-9.16284424 \mathrm{e}-02 \\
(8.7316844 \mathrm{e}-02) \\
\end{array}$ & -1.04938 & 0.29498581 \\
\hline \multirow{2}{*}{$\begin{array}{l}\text { Threshold Value } \\
=0.001713\end{array}$} & \multirow{2}{*}{$\begin{array}{l}\text { Residuals } \\
\text { variance }= \\
6.889 \mathrm{e}-05\end{array}$} & \multirow[b]{2}{*}{$\mathrm{AIC}=-2501$} & \multicolumn{2}{|c|}{ Proportion of points in each regime } \\
\hline & & & $\begin{array}{l}\text { Low regime }= \\
63.32 \%\end{array}$ & $\begin{array}{l}\text { High regime }= \\
36.68 \%\end{array}$ \\
\hline
\end{tabular}

Table 11: SETAR Model with one threshold for the Croatian industry dynamics [Author].

The results in table 11 illustrate estimates of SETAR specification for the eurization dynamics in Croatia. Diagnostics checking show no misspecification of the presented estimates. The 
model estimates points on the existance of threshold in the eurization dynamics wih significant autoregression component during the regime of low dynamics. The dynamics in the high regime seems to be constant. Following AIC SETAR model is the most appropriate specification among tested models to explain eurization dynamics in Croatia. The paper illustrated nonlinear and threshold dependent dynamics of the eurization growth in Croatia.

\section{Concluding remarks}

There are several conclusions that can be drawn out of the research presented in this paper. Firstly, the phenomenon of financial eurization is very prominent in Croatian financial system and due to that fact many constraints are imposed on Croatian economy and its competitiveness. Taking into account high degree of openness in Croatian economy the problems arising out of financial eurization need special attention of monetary authorities. Secondly, nonlinear models outperform its linear $\operatorname{ARMA}(3,0,0)$ counterpart in explaining financial eurization development pattern in Croatia indicating presence of hysteresis. Due to the phenomenon of hysteresis, a nonlinear class model may be more appropriate generally for explaining financial dollaerization pattern behaviour. Nonlinearity test supports existence of nonlinearity of eurization dynamics in Croatia. Furthermore, eurization growth phenomenon in Croatia is very persistent and that might be the case due to poor macroeconomic management and unstable economic conditions. Conclusively, financial eurozation is often the result of nominal and real exchange rate changes as well as the changes in inflation and its level. But following the Croatian example, to de-eurize or resolve the problem of financial eurization it is necessary to achieve overall macroeconomic stability and not only the exchange rate stability.

\section{References}

[1] Bošnjak, M., Bilas, V. and Novak, I. (2016). Modeling Exchange Rate Volatilities in Croatia. Ekonomski vjesnik / Econviews - Review of Contemporary Business, Entrepreneurship and Economic Issues, 29(1), 81-94.

[2] Box, G. E. P. and Jenkins, G. M. (1976). Time Series Analysis, Forecasting and Control. San Francisco: Holden-Day.

[3] Brown, M. and Stix, H. (2014). The Euroization of Bank Deposits in Eastern Europe. 59th Panel Meeting of Economic Policy, April.

[4] Chan, K. S. and Tong, H. (1986). On estimating thresholds in autoregressive models. Journal of Time Series Analysis, 7(3), 179-190.

[5] Chmelarova, V. and Schnabl, G. (2006). Exchange Rate Stabilization in Developed and Underdeveloped Capital Markets. https://www.ecb.europa.eu/pub/pdf/scpwps/ecbwp636.pdf [Accessed 15/10/16].

[6] De Nicolo, G., Honohan, P. and Ize, A. (2003). Dollarization of the Banking System: Good or Bad?. International Monetary Fund. Working Paper No. 03/146.

[7] De Nicoló, G., Honohan, P. and Ize, A. (2005). Dollarization of Bank Deposits: Causes and Consequences. Journal of Banking and Finance, 29(7), 1697-1727. 
[8] Erasmus, L., Leichter, J. and Menkulasi, J. (2009). De-dollarization in Liberia: Lessons from Cross-country Experience. International Monetary Fund. Working Paper No. $\mathrm{WP} / 09 / 37$.

[9] Globan, T., Arčabić, V. and Sorić, P. (2016). Inflation in New EU Member States: A Domestically or Externally Driven Phenomenon?. Emerging markets finance and trade, 52(1), 154-168.

[10] Goodfriend, M. (2007). How the World Achieved Consensus on Monetary Policy. The Journal of Economic Perspectives, 21(4), 47-68.

[11] Gros, D. Alcidi, C. and Giovanni, A. (2012). Central Banks in Times of Crisis The FED versus the ECB, Europen Unin Policy Department A: Economic and Scientific Policies. http://www.europarl.europa.eu/document/activities/cont/201207/20120702ATT48168/201 20702ATT48168EN.pdf [Accessed 2/11/16].

[12] Hamilton, J. D. (1989). A New Approach to the Economic Analysis of Nonstationary Time Series and the Business Cycle. Econometrica, 57(2), 357-384.

[13] Ivanov, M., Tkalec, M. and Vizek, M. (2011). Determinants of financial euroization in a post-transition country: Do threshold effects matter?. Czech journal of economics and finance, 61(3), 230-251.

[14] Keenan, D. M. (1985). A Tukey Non-additivity Type Test for Time Series Nonlinearity. Biometrika, 72(1), 39-44.

[15] Kokenyne, A., Ley, J. and Veyrune, R. (2010). De-dollarization. International Monetary Fund, Washington. Working Paper No. WP/10/188.

[16] Madsen, H. (2008). Time Series Analysis. London: Chapman \& Hall/CRC.

[17] Mance, D., Žiković, S. and Mance, D. (2015). Econometric Analysis of Croatia's Proclaimed Foreign Exchange Rate. South East European Journal of Economics and Business, 10(1), 7-17.

[18] Mwase, N. and Kumah, F. Y. (2015). Revisiting the Concept of Dollarization: The Global Financial Crisis and Dollarization in Low-Income Countries. International Monetary Fund, Working Paper No. WP/15/12.

[19] Ostojić, S. and Mastilo, Z. (2013). Effects of Unofficial Euroisation in Serbia With Regards to the Inflation and Real GDP. Research in Applied Economics, 5(4), 48-79.

[20] Palić, I., Dumičić, K. and Šprajček, P. (2014). Measuring real exchange rate misalignment in Croatia: cointegration approach. Croatian Operational Research Review, 5(2), 135-148.

[21] Priestley, M. B. (1981). Spectral Analysis and Time Series. London: Academic Press.

[22] Rodrik, D. (2008). The real exchange rate and economic growth. Brookings papers on economic activity, 39(2), 365-439.

[23] Samreth, S. (2011). An Empirical Study on the Hysteresis of Currency Substitution in Cambodia. Journal of Asian Economics, 22(6), 518-527.

[24] Tong, H. (1990). Nonlinear Time Series, A Dynamical System Approach. Oxford: Clarendon Press, Oxford.

[25] Tsay, R. S. (1986). Nonlinearity Tests for Time Series. Biometrika, 73(2), 461-466.

[26] Uribe, M. (1997). Hysteresis in a Simple Model of Currency Substitution. Journal of Monetary Economics, 40(1), 185-202.

[27] Valev, N. T. (2010). The Hysteresis of Currency Substitution: Currency Risk vs. Network Externalities. Journal of International Money and Finance, 29(2), 224-235. 
[28] Zettelmeyer, J., Nagy, M. P. and Jeffrey, S. (2010). Addressing private sector currency mismatches in emerging Europe. European Bank for Reconstruction and Development. Working Paper No. 115.

\section{Appendix}

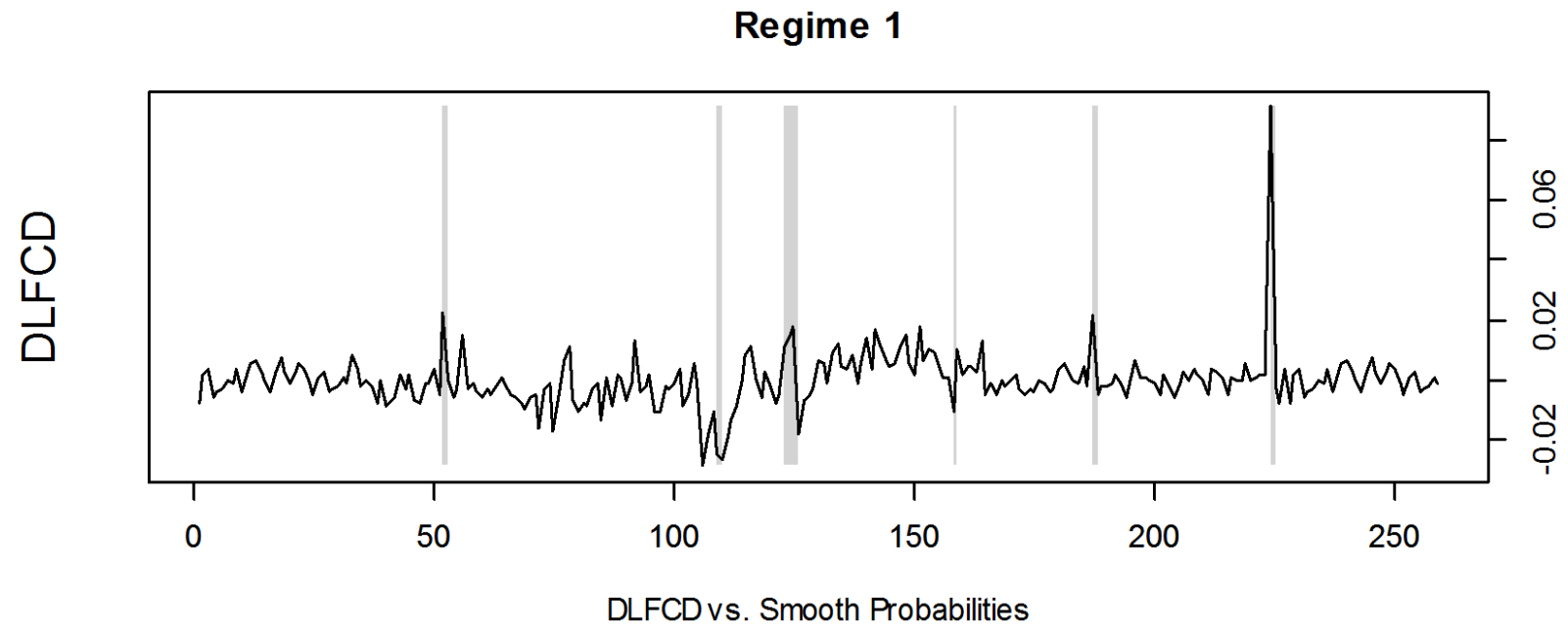

Figure 1: MS AR model of eurization dynamics in Croatia with regime specific mean and coefficients

\section{Regime switching plot}

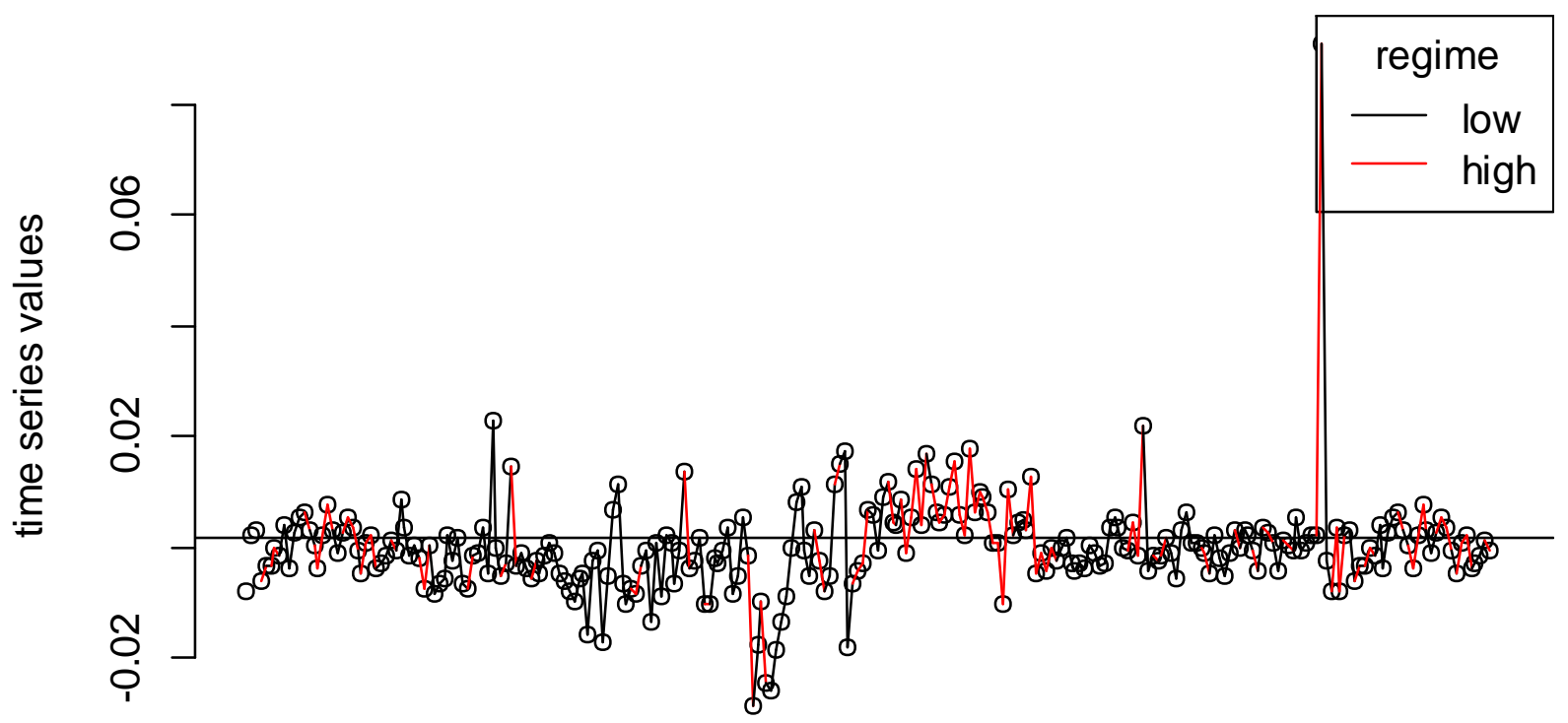

Figure 2: SETAR model specification of eurization dynamcs in Croatia 